\title{
Understanding Accumulation: The Relevance of Marx's Theory of Primitive Accumulation in Media and Communi- cation Studies
}

\author{
Mattias Ekman \\ Department of Media Studies, Stockholm University, Stockholm, Sweden, ekman@jmk.su.se
}

\begin{abstract}
The aim of this article is to discuss and use Marx's theory on primitive accumulation, outlined in the first volume of Capital, in relation to media and communication research. In order to develop Marx's argument the discussion is revitalized through Harvey's concept of accumulation by dispossession. The article focuses on two different fields within media and communication research where the concept of accumulation by dispossession is applicable. First, the role of news media content, news flows and news media systems are discussed in relation to social mobilization against capitalism, privatizations, and the financial sector. Second, Marx's theory is used to examine how communication in Web 2.0 and the development of ICTs could advance the processes of capital accumulation by appropriating the work performed by users of Web 2.0 and by increasing the corporate surveillance of Internet users. In conclusion, by analyzing how primitive accumulation is intertwined with contemporary expanded reproduction of capital, the article shows that Marx's theory can contribute to critical media and communication research in several ways.
\end{abstract}

Keywords: Marx, Capitalism, Capital Accumulation, Accumulation by Dispossession, Political Economy, News Media, Commodification, Privatization, Web 2.0, Facebook

Acknowledgement: I would like to express my gratitude to Andreas Widholm for his helpful comments on the article.

\section{Introduction}

The current global crisis of capitalism has inspired numerous social theorists to both revitalize and reinvent many of the key arguments and trails within Marx's magnum opus Capital. Without any other comparison to the increasing body of literature that draws on Capital, this article will be yet one more attempt to connect to the seminal work that has been counted out so many times before by the apologetics of capitalism.

The purpose of this article is to discuss Marx's $(1867,1990)$ theory of original/primitive accumulation ("ursprüngliche Akkumulation"), described in the first volume of Capital, and its relevance for analyzing the role of (mass) media, online communication and communication systems, in the process of capital accumulation. In order to revitalize Marx's argument in Capital, the theory of origi$\mathrm{nal} / \mathrm{primitive}$ accumulation is updated in relation to Harvey's $(2003 ; 2006 ; 2010 \mathrm{a})$ theory of "accumulation by dispossession". Harvey draws on Marx's discussion of primitive accumulation in order to unfold the neo-liberal shift within the development of global capitalism.

Following a basic theoretical understanding of primitive accumulation and accumulation by dispossession the article addresses two key ideological aspects of news media content and media structures in relation to the processes of accumulation by dispossession. The article examines the media representation of social struggle against capital accumulation, and how news media content and news media systems facilitate capital accumulation in the finance sector. Furthermore the article taps into how surplus value is produced in the realm of Internet use, particularly Web 2.0, and the development of communication technology. Here, some thoughts on how everyday Web surfing could be understood as surplus labour and how users are transformed into commodities will be addressed. In relation to the discussion on everyday online activities, Marx's theory of original/primitive accumulation provides an understanding of new forms of exploitation by the appropriation of intellectual assets and creativity in the field of cultural production, distribution and communication in the Web 2.0. Here the article discusses how the commodification of free time, the self and social relations, play a key part in the political economy of social media and the Internet. Included is also a short section that discusses if Internet surveillance, and the commercial gathering, owning and processing of personal information, could be understood as an underlying threat to subjects, and a part of what Žižek (2008) defines as the objective violence of capitalist exploitation. 
The article combines the results of empirical research on news media with examples of how the everyday use of social media and intellectual assets and creativity in the field of cultural production/distribution could be explained through a Marxist theory of capital accumulation in a time of systemic crisis. Harvey's updated version of Marx's notion of original/primitive accumulation provides a strong argument for understanding the recent development of late capitalism.

\section{The Process of Capital Accumulation}

The immanent driving force of capitalism is the endless accumulation of capital, a process where capital is accumulated for the sake of accumulation, or as Marx $(1867,1990,595)$ put it "accumulation for accumulation's sake, production for production's sake". The very basic formula of capital accumulation, outlined by Marx $(1885,1992)$ in the second volume of Capital, draws on how capital is circulated through several key phases:

$$
M-C(L p / M p) \ldots P(v / C) \ldots C^{\prime}-M^{\prime}
$$

To put it simple - the accumulation of capital is obtained by the circulation of capital, where money (M) is transformed into commodities (C) by the purchase of labour power (Lp) and means of production (Mp). To secure accumulation, the money needs to be greater in the end of the process than in the beginning, which means that the value of the produced commodity is higher than the value of the commodities used as inputs. In the production process the value of labour power and the means of production take the form of productive capital $(P)$ when attached to the produced commodity. The value of labour force $(\mathrm{v})$ equals the costs of the labour power bought (wages) and the value form of means of production (c) equals the cost of the means used (constant capital). So, surplus value is generated when the commodity is sold at a higher price than the costs of production, which is made possible by surplus labour (unpaid labour time). So what basically creates surplus value is the amount of labour time that is not paid for by the capitalists. When the produced commodity $\left(C^{\prime}\right)$ is sold, capital once again enters the process of circulation in the form of (new) money (M'), and; the process of capital accumulation is thereby maintained (Marx 1867, 1990; Harvey 1982, 2006, 156ff; Fuchs 2011, 138).

Marx's theory of capital accumulation is highly complex and detailed (the whole second volume of Capital is basically an outline of the trails of capital accumulation), but its still possible to simplify it in this manner without losing too much of its inner nature. Under ordinary circumstances, capital accumulation is secured through expanded reproduction ${ }^{1}$. In this process of reproduction, not only commodities and surplus value are reproduced, but also the whole relationship between capital and labour - between capitalists and wage labourers (Marx 1967/1990, 578). And since surplus value relies on the exploitative relation between capital and labour force, the circulation of capital is ultimately the reproduction of exploited wage labour by capitalists. The commodity labour power $(L p)$ is subordinated to processes of absolute or relative exploitation. The former refers to the extension of the amount of time each worker needs to put in, and the latter to the intensification of the labour process (Mosco 2009, 131).

The circulation of capital is an endless process, and given the inner contradictions of accumulation, capitalism eventually faces systemic crisis. The historical Marxist debates over what type of crises capitalism is undergoing tend to shift. Luxemburg (1913/2003) stresses the problems of under-consumption to explain systemic crises, but under-consumption is hardly a sufficient explanation of the crises within capitalism today. Harvey argues that capitalism is currently facing an overaccumulation crisis $^{2}$, because we are experiencing a situation "when both surplus capital and labour exist but there are no way to bring them together" (Harvey 2006, 96). The over-accumulation crisis manifests itself when there are superfluous commodities, money and productive capacity form simultaneously with a surplus of labour power, but with the lack of "profitable opportunities" for capital to expand (Harvey 2003, 88). In order to deal with an over-accumulation crisis, capital tries to expand reproduction through temporal or spatial shifts. Harvey $(2003,89)$ calls these "spatiotemporal fixes". For example, by investing surplus capital and labour in long-term (large scale pub-

\footnotetext{
${ }^{1}$ Marx (1867, 1990, 711ff) distinguishes between "simple reproduction" and "expanded reproduction" (Marx 1867, 1990; $1885,1992)$. Simple reproduction is basically the reproduction of capital-labour relations without any accumulation of capital.

${ }^{2}$ The definition of what characterizes over-accumulation crises is highly simplified here, since systemic crises tend to inherit several dimensions (see Harvey 2003; 2006; 2010b, for a more in-depth analysis of systemic crises, \& see Fuchs 2011 , for an overview of different contemporary crises-explanations).
} 
lic) projects, or by relocating the surplus of capital and labour to other geographical spaces (Harvey 2006, 96). Capitalists have a tendency to expand reproduction geographically by relocating the purchases of labour power or means of production elsewhere, and thus creating new spaces for the accumulation of capital. Since capitalism is a global system, expanded reproduction often results in a situation where crises are moved around geographically. The spatio-temporal fixes are reliant on and thrive from the advancement of communication technology and systems. Advancements in transport and communication that compresses time-space relations are therefore at the heart of temporal or spatial shifts. In search for new ways to invest surplus capital, capitalists also strive to appropriate new forms of labour and new resources, both material (such as natural resources), and immaterial (such as knowledge), into the circulation of capital. By doing so, it is possible to create surplus value from previously unexploited work and resources. One way to understand the process of appropriation of labour and resources, in contemporary over-accumulation crises is by looking back at the origins of the capitalist mode of production. In order to explain the relation between geographical imperialism and global capital, Harvey (2003; 2006; 2010a) draws on Marx's discussion of "ursprüngliche" or primitive accumulation in the first volume of Capital, in order to unfold the neo-liberal shift in our contemporary societies.

\subsection{Primitive Accumulation}

In Marx's (1867, 1990, ch.26) discussion in Capital, primitive accumulation is the process in which pre-capitalist modes of production are transformed into capitalism - it is the starting point of the capitalist mode of production. Thus it is also the process, in which the producers are separated from their means of production and where they are transformed into wage labourers that are sold on the market (i.e. labour power becomes a commodity). So primitive accumulation also constitutes the very process, in which the working class is formed:

The capital-relation presupposes a complete separation between the workers and the ownership of the conditions for the realization of their labour. As soon as capitalist production stands on its own feet, it not only maintains this separation, but reproduces it on a constantly extending scale. The process, therefore, which creates the capital-relation can be nothing other than the process which divorces the worker from the ownership of the conditions of his own labour; it is a process which operates two transformations, whereby the social means of subsistence and production are turned into capital, and the immediate producers are turned into wagelabourers. So-called primitive accumulation, therefore, is nothing else than the historical process of divorcing the producer from the means of production. It appears as 'primitive', because it forms the pre-history of capital and of the mode of production corresponding to capital. (Marx 1867/1990, 874-875)

In Marx's depiction of how the old feudal system was transformed into capitalism, the liberal version of capitalism mounting like a natural evolution of capital is confronted by a much blunter version of reality. The transformation of the feudalist system was a process marked by a brutal and often violent expropriation of capital. The enclosure of the commons, the colonial system, imperialism, the use of slave labour, the expulsion of peasant populations forced into industrial wage labour, etc., were often violent. So in Marx's version of the "ursprüngliche" or primitive accumulation, violence plays a central part. As Marx $(1867,1990,875)$ argues in a famous statement in Capital; "...the history of this, their expropriation, is written in the annals of mankind in letters of blood and fire". Undoubtedly Marx's depiction of the historical process of capital is only partly true; there were also peaceful or at least less violent transformations (Harvey 2010a, 304f). Nevertheless, Marx exposed the liberal myth, painting a picture of a smooth transformation originated from the shoulders of hardworking men with specialized labour skills that became employers - that story was anything but true.

For the labourer, the process of primitive accumulation was double sided, workers were set free from the feudal oppression system, slavery, etc. just to become entrapped in a new relation of exploitation, the system of wage labour - indirect forced labour. Or as Marx argues in Grundrisse, in a comment on the indignation of a former slave master on the fact that slaves were freed from bondage, but did not become wage labourers in the plantations owned by the latter:

They have ceased to be slaves, but not in order to become wage laborers, but, instead, selfsustaining peasants working for their own consumption. As far as they are concerned, capital does not exist as capital, because autonomous wealth as such can exist only either on the basis of direct forced labour, slavery, or indirect forced labour, wage labour. (Marx 1857/1993, 326) 
We will return to some contemporary examples of how self-sufficient peasantry and collectively owned and organized agricultural production (mobilized in the form of social movements such as Movimento dos Trabalhadores Rurais Sem Terra [MST] and Via Campesina) is fighting the expulsion and enforcements of populations into wage-labour, and how media plays a crucial part in justifying the expulsions in the name of economic development.

So, if primitive accumulation is the starting point of the capitalist mode of production, how could it help us understand processes of capital accumulation in contemporary late capitalism? Harvey (2003; 2005; 2006; 2010a) argues, inspired by Luxemburg (1913/2003), that many of the specific features of primitive accumulation are highly visible in today's modern neo-liberal capitalism. For Marx the 'normal' process of accumulation is expanded reproduction, but Luxemburg (1913/2003) argued that the continuous accumulation of capital also inherited a "primitive" feature. This formed one key argument in her theory of imperialism - capital always creates new geographical spaces of exploitation, or "capitalism's penetration of non-capitalist societies" (Callinicos 2009, 40). Luxemburg's theory can also be used for understanding how other milieus outside the circulation of capital are colonised by capital. Marxist feminists have attached Luxemburg's idea of colonialism to the reproductive work done by women in the household (Hartsock 2006). Reproductive work constitutes "an inner colony and milieu of primitive accumulation", by ensuring the reproduction of (male) wage labourer (Fuchs 2011, 282).

Harvey (2006) argues that current accumulation of capital inherits characteristics from the original process as well. In fact, accumulation through expanded reproduction and by dispossession "are organically linked, dialectically intertwined" with each other (Harvey 2003, 176). There are at least two key arguments that locate specific features of primitive accumulation (embedded) in modern capitalist reproduction. First there are numerous examples of population expulsion and appropriations of land (particularly in Latin America and Asia), there are violent extractions of natural resources (all over the global south); and there is systematic and sometimes extreme violence against those who struggle against these processes all over the global south. The level of violence has also been intensified in some instances (Harvey 2010a, 308). Secondly, it seems that the ongoing reproduction of capitalism continues to involve some of the characteristics of primitive accumulation, such as increasing national debt and what Marx (1867/1990, 777ff) identified as the growing credit system. The whole endeavour of the financial credits and loans handed out by IMF and the World Bank have a striking resemblance to the emerging credit system and the state as actor in processes of privatization several hundred years ago. Harvey $(2003 ; 2005 ; 2006 ; 2010 a)$ describes these features of primitive accumulation as "accumulation by dispossession". It could be described as the (futile) neo-liberal answer to a continuous decline in global growth (Harvey 2003, $145 ; 2006,42)$. Accumulation by dispossession is characterized by four key elements: privatization, financialization, the management and manipulation of crises and state redistributions (Harvey 2006)

\subsubsection{Privatization}

Accumulation by dispossession is manifested by the privatization of public assets - the appropriation of the commons. These privatizations include everything from natural resources (water, land, air), infrastructure (public transport, telecommunications, energy supplies), social systems of redistribution, social services, healthcare, education, public institutions, public housing, warfare, and so on, basically anything that is not already included in the circulation of capital. There is also a privatization of immaterial assets such as knowledge, genetic material, and reproduction processes. All these areas, which previously were outside capital accumulation because they were regarded as commons, public services, of national interest, etc., are appropriated to different degrees in the neo-liberal model of capitalism. By adding them to the circulation of capital they are incorporated into capitalist property relations, thus they also transform the social relations of subjects in society. Students, patients, water drinkers, citizens, etc., are transformed into clients, customers and buyers of goods and services as commodities. The process of accumulation by dispossession is therefore ultimately a process of social exploitation. The contemporary process of privatization has been defined by Indian writer and activist Arundhati Roy (2001 in Harvey 2006, 44-45) as a "barbaric dispossession on a scale that has no parallel in history".

Processes of privatization can be swift and clean without any particularly struggle or use of force, this is predominantly the case in the global north where the state has been the main propagator of privatizations. But the processes of dispossession in the global south are often followed by harsh or violent expulsions of rural populations and appropriations of everyday natural resources (Harvey 2006, 45). Sometimes the outcome of dispossessions is open social struggle and sometimes capital even loses. This was the case during the water wars in Cochabamba, Bolivia, in the 
late 1990s. During a wave of privatizations orchestrated by the IMF, the city's public drinking water was sold to the US-owned company Bechtel, which resulted in increasing water prices and a limitation of supplies. The dispossession of water resulted in a hard struggle for the right to water as basic human asset, which ultimately forced the city to re-buy the water rights (Olivera and Lewis 2004). So processes of privatization can also sharpen class struggle and class-consciousness in various ways.

Privatization also includes warfare. War is in fact an increasingly commodified endeavour, where private companies make huge profits in security and torture. Warfare is simply a process in which huge transfer of government funding to private owned capital takes place. Luxemburg's $(1913,2003,434)$ discussion of "militarism as a province of accumulation" of the early 20th-century could basically be an explanation of today's late capitalist imperialism, in which the militaryindustrial complex plays a key role in facilitating expanded reproduction of capital and 'creating' new spaces of exploitation by violence and destruction (Žižek 2009).

The appropriation of public assets by dispossession creates the appearance of a growing accumulation because new areas of exploitation and processes of surplus value are added to the circulation of capital.

\subsubsection{Financialization}

The second characteristic of accumulation by dispossession is financialization. The enormous increase in financial capital is intertwined with deregulations of markets, a rapid development of information and communication technology and the processes of privatization. Speculation in the capitalist financial system has contributed to an apparent economical growth through major capital redistributions. The financial system holds a particularly important position in the "thievery" of public assets such as pensions (Harvey 2006, 45). The on-going build-up of fictitious capital, through hedge funds, ponzi schemes and asset stripping, together with an overall emphasis on stock value, generates an apparent economical growth. These processes were depicted as one main factor when the global economic crisis set in 2008. Financialization, and the increasing importance of the financial sector, also mark the stagnation phase in the so-called Kondratiev cycles that distinguish growth and stagnation within the capitalist world system over historical periods (Arrighi 2010). Marx $(1867,1990,920)$ stressed the importance of the credit system in order to understand the growing power of capital over states and the rapid (spatial) centralization of capital. As an example the IMF and the World Bank are doing the job by setting "up micro-credit and micro-finance institutions to capture what is called 'the wealth at the bottom of the pyramid' and then suck out all that wealth to support ailing international financial institutions....and use that wealth to pay the asset and merger games..." (Harvey 2010a, 272). Media researcher Almiron (2010) highlights the growing relationship between financial capital and news media organizations. News media are increasingly dependent on financial actors, such as banks, and therefore financialization has profound consequences on news practices and content (Almiron, 2010).

\subsubsection{The Management and Manipulation of Crises}

Third, the neo-liberal turn in capitalism has resulted in orchestrated economic crises. Crises permit rapid redistribution of assets and economic shock therapy in the form of structural adjustment programs. Orchestrated crises were more or less the rule in Latin America during the 1980s and the 1990s. Debt crisis in single countries enabled quick changes to the IMF's structural adjustment programs, and thereby transformed the national economies according to the neo-liberal model propagated by transnational institutions such as IMF and the World Bank. These provoked crises resulted in a massive relocation of capital and created an apparent accumulation of capital. The crises produced a large population of unemployed labour force that created "a pool of low wage surplus labour convenient for further accumulation" (Harvey 2006, 47). These crises also expose the use of violence that is applied in order to secure the interest of capital. The violence emanating in the intersection of capital and states is manifested through brutal suppression of protests, labour organizing and social movements all over the global south.

\subsubsection{State Redistribution}

In neo-liberal capitalism, the state is transformed into the most central actor in the redistribution (privatization) of public assets. The privatization of the public sector, or large cuts in the funding of public services, constitutes the fourth key element in accumulation by dispossession (Harvey 2006, 48). There are numerous examples of how the state, despite the political character of the ruling government, has played a key role in processes of privatization. For example; the privatization of 
the pension system under fascist dictatorship (in Chile 1980), during social-democratic governments (in Sweden in the late 1990s) and during the Peronist rule in Argentina (in the 1990s), privatization of public housing in the UK during Thatcher's government in the 1980s, during both socialdemocratic and centre-right wing (local) governments in Sweden over the past fifteen years, and the privatization of agricultural land during the nationalist rule [PRI] in Mexico in the 1990s. The list of privatizations is almost endless. In the greater perspective, state redistributions spawn massive relocations of public assets to private ownership. The transfer of public assets into the private sector is not only about the privatization of social services such as education, health care, social work, infrastructure, pensions, etc., but it also involves pure money transfers to the business sector in the form of bank rescue programs and government investment in the private sector. In the U.S. the "corporate welfare programs" which signify the neo-liberal turn, have resulted in an enormous redistribution of taxpayer's money into the hands of the private sector (Harvey 2006, 49).

The effects of state redistribution are sometimes violent. There are several cases of direct warfare against social mobilization, for example against social movements in Chiapas and Oaxaca, Mexico, trade unionists in Colombia, the organized landless rural workers in the MST in Brazil, the Adivasi in India, and so on. State redistribution may also involve a more latent symbolic violence against people who are forced from their homes due to property speculation that surfaced in the aftermath of the large privatization of public housing (as in London), or the expulsion of large populations caused by the private expropriation of natural resources (everywhere in the global South). The formation of such indirect violence is a key attribute in several processes in late capitalism. We will now tap into what distinguishes the violence of original/primitive accumulation in relation to our contemporary era of new imperialism through accumulation by dispossession.

\subsection{The Role of Violence in the Process of Accumulation}

In order to understand the neo-liberal turn in capitalist accumulation and the processes that mark the global expansion of capital, we must consider how global capital is connected to territorial geo-politics in a neo-imperialist manner. Primitive accumulation or accumulation by dispossession is basically a form of imperialism (Harvey 2003). Capitalism inherits a contradiction between the global expansion of capital, and a territorial logic of power (geopolitical behaviour of nation states) (Harvey 2006, 105). Harvey's (2003) analysis of imperialism shows that geopolitical rivalry and global capital accumulation coincide and reshape the basis of accumulation. The analysis of capital accumulation and the geopolitical development that consists of both primitive accumulation and expanded reproduction reveal that violence plays a central role in the expansion of the capitalist world system. Violence is simply part of the inner logic of accumulation, it surfaces when its needed as a necessary component in securing the "right" of capital. Wallerstein (2001:29) argues that the problems of expansion in a period of systemic crisis will be accompanied with potentially more violent capital expansion. Parallel to the political decline due to the weakening position of nation states in relation to transnational institutions such as the IMF/WB, the process will undoubtedly increase the amount of daily violence in the world system. Violence emerges at the intersection of global capital accumulation, especially in the accumulation by dispossession, and the territorial geopolitics of the U.S. as the leading hegemon in the world. So violence is inevitably part of a system that breeds further economic and social inequality, and thus it can be understood as an intra-systemic necessity.

Let us now turn to the specific role of violence in the accumulation by dispossession. The capitalist system relies on both active and underlying violence, as means of securing accumulation and the private control over the means of production. Žižek (2008) distinguishes between subjective and objective violence. Subjective violence, such as interpersonal aggression, crime, terror or the repressive apparatus of the state, is overt and exercised with a specific intent of some sort (pathological, political, patriarchal, religious, etc.). Objective violence is on the other hand built into the practices of capitalism, and manifested in overt discrimination, structural racism, economic destitution, or other forms of more subtle exploitation. The two forms of violence are relational. Subjective violence, for example the suburban riots in cities like Paris and London, can be comprehended in its relation to objective violence, the annihilation of social trust caused by economic exploitation, expulsion, racism and discrimination. Subjective violence is just the more visible of the two (Žižek 2008). As objective violence could be viewed as a consequence of the exploitative social relations in capitalism, it also appears as an underlying threat of violent acts against those who contest it. In this sense, the objective violence is part of what Gramsci defines as the consent of hegemony, a form of violence that intertwines the two forms of capitalist dominance, force and consent, or to put it in Gramsci's (1929-35, 1971, 263) words: "hegemony protected by the armour of coercion". Subjective and objective violence are two different manifestations of systemic violence constituted in 
relation to socio-political power and economic exploitation. The global capitalist accumulation by dispossession is often marked with overt systemic violence in the form of crisis therapy, physical destruction of traditional means of production, and material expropriation through warfare and occupation, as we have seen in Iraq (Žižek 2009,17), and by an increasingly violent, economic impoverishment of subjects in the global South (Ekman 2011). Violence becomes a common feature of capitalist exploitation processes, much so because the system tends to increase an extreme asymmetry in the distribution of assets during processes of expropriation. Objective violence also includes symbolic violence, or what Galtung (1990) defines as "cultural violence". It refers to those aspects of culture that "can be used to justify or legitimize direct or structural violence" (Galtung 1990, 291). So in relation to Žižek's model, cultural violence could include those aspects of news media that legitimize the use of force against social mobilization and protests, or to news media that justifies war.

So, in conclusion, we can view the historical processes of primitive accumulation preceding the capitalist mode of production, i.e. as a historical formation, characterized by colonialism, imperialism, mass expulsions of populations, the creations of mass industries, the working class and capitalists. But we can also consider primitive accumulation as a continuation of characteristics that are embedded in the capitalist mode of production. The never-ending appropriation of labour and recourses through time and space, forced into capitalist property relations, are undoubted tainted by many of the features described by Marx $(1867,1990)$. At the end, the main feature of primitive accumulation is the forced separation of means of production from the producers.

\section{The General Role of Media and Communication in the Accumulation of Capital}

There is a bundle of theoretical and empirical work that draws on Marx's theory of capital in order to understand the role of media and communication in the accumulation of capital (cf. Mosco 2009; McChesney 2007). Fuchs (2011, 141ff) distinguishes between several aspects, both internal to media and communication (as industries) and external to media and communication (as general accounts) that might illuminate its specific role in the processes of capital accumulation. I will only touch upon a couple of aspects that could be useful in order to understand media and communication in relation to primitive accumulation or accumulation by dispossession. The first aspect deals with the ideological dimension of media content and the structural relations between news systems and the financial sector. The ideological element is crucial to the reproduction of capitalism in various ways, economically, politically, juridical and so forth. For example, the media have a powerful position in reifying social relations by normalizing and facilitating the privatization of everyday life. For example, media content produces the audiences as consumers of goods and services. The aim here is not to evoke too much of the historical discussion of ideology critique, but to distinguishes some core ideological elements in relation to accumulation by dispossession. Second, the discussion on how the free time of individuals is appropriated and transformed into surplus labour, touches upon the notion of how social media work as an infrastructure for advertisement that advances capital accumulation (cf. Fuchs 2011, 149). Social media and modern information technology are crucial in the compression of time and space in the everyday circulation of commodities. We are, when using smart-phones, going online, and so on, constantly targeted as consumers. In fact, most parts of the Internet have been commercialized, and processes of commodification constantly subjugate users. There is not much that separates commercial from non-commercial content on the Internet (Hesmondhalgh 2007, 259).

\subsection{News Media and the Naturalization of Accumulation by Dispossession}

I would like to address a couple of cases, in which both structural and ideological dimensions of news media could be pinpointed in relation to processes of primitive accumulation and accumulation by dispossession. The first case discusses the role of news in relation to the privatization of public services and how news media coincide with the interest of, and facilitates the practices of, the financial sector (cf. Almiron 2010; Hope 2010). The second example deals with the media representation of the global justice movement, global protests and the World Social Forum in Swedish mass media (Ekman 2011).

\subsubsection{Endorsing Privatization and Facilitating Financialization}

In the 1980s and the 1990s most of the countries in the world were swept along the wave of privatizations that mark the neo-liberal turn in the global capitalist system. In Sweden, where the 
public sector previously was well developed and economically prioritized, processes of deregulation and privatization transpired in an increasing speed. The situation in Sweden reflected, more or less, the tendencies that were visible in the rest of Western Europe. In correspondence to the rapid wave of privatization in the 1990s the noun "market" emerged as one of the most prominent agents in the news on economical matters (cf. Mårtenson 2003; Viscovi 2006). The representation of the "market" as a unified actor, which reacts on political decisions, declares which political actors are good or bad, and decides on how to view the overall economic condition, changed the discourse of news reporting on economical matters (Mårtenson 2003). The mediated notion of the "market" emerged as an ideological element to the neo-liberal turn and the massive deregulation of the capitalist economy. In correspondence to the emergence of the "market", news turned to the financial sector, and the stock market became a prevailing feature. This also meant that actors from the financial sector tended to dominate as experts in the everyday news flow. The representation of economic issues were signified by a shift from labour markets, unions, etc. to the financial markets and the construction of the mediated citizen as a private-economic subject (as opposed to wage-labourer, or someone outside the realm of finance speculation) (Viscovi 2006). Almiron's $(2010,167)$ study on two leading Spanish newspapers in 2006 shows a similar result. Financial actors and indicators dominate the news, and Almiron $(2010,167)$ conclude that: "the lack of independent journalistic investigation in most of the information was almost absolute". The paradigm shift within the news, identified by Mårtenson (2003) and Viscovi (2006), corresponded with the process of financialization in accumulation by dispossession.

Let's consider one specific Swedish case that signifies the role of news media in endorsing privatization by facilitating the transfer of ordinary people's savings into the financial market, and one truly global phenomenon that shows how news flows become intertwined with financial flows and how the interests of financial news coincide with the interests of financial actors.

In June 2000 the publically owned telecommunication company Telia was partly privatized (30 percent was sold to the public). Almost one million Swedes became shareholders after substantial commercial advertising (in television, newspapers and in the public space) and after a political campaign (the whole privatization was endorsed on a personal level by the minister of finance) aided by news media. In the process of privatizing part of the company, the stock was promoted as a "people's-share"4 in the news. This ideological noun was used in order to smoothen out the fact that the public now could buy something that was already in their possession, and with the opportunity to make a profit ${ }^{5}$. For example, a couple of weeks prior to the privatization, the second largest tabloid, Expressen, published several articles endorsing the readers to purchase shares. One article used the luring headline: "Eight reasons in favor of Telia...This is why the share might become a winner" (Bolander 2000a). Articles, both in tabloids and dailies, used financial actors to boost the privatization and the opportunity to make a quick profit: "Stock market experts believe in a killing on the market" (headline in Bolander 2000b), "Telia is predicted a good start. Experts advise to purchase the new people's-share" (headline in Magnusson, 2000). Some articles were just plain buyers guides: "How to purchase Telia - the new people's-share" (headline in Norlin, 2000), "How you can purchase the people's-share" (headline in Wedel, 2000). The list of articles aiding the privatization could be extended. The whole construction of a "people's-share" is very much a media phenomenon interlinked to the increasing focus on the financial sector. When searching the largest Swedish press archive Mediearkivet, it reveals that the term "people's-share" appeared in a total of 186 articles prior to the privatization of Telia. But from the year 1999, when the privatization process started, and onwards, it has appeared 1113 times, peaking at 400 articles in the year 2000. The seven biggest Swedish newspapers published 220 articles containing the word "people's-share" in the year 2000 alone.

The privatization of public infrastructures such as telecommunication services corresponds to similar processes of marketization within news production (Almiron 2010). The mounting commercialization of news and the increasing symbiosis between financial news and the financial sector, paralleled by limited economic recourses and increasing time limits within journalistic production, results in a very uncritical journalism (of course with notable exceptions). The harsher conditions of news journalism as a result of increasing demands of higher profit margins (obtained from what Marx defines as relative surplus value, 1867, 1990, 429ff), simultaneously with a decrease in sales, make financial news an easy target for economically well-situated actors in the financial markets.

\footnotetext{
${ }^{3}$ The "market" will be used in brackets to signify its ideological status.

${ }^{4}$ The noun "people's-share", corresponds to the concept of the "people's-home", a term used to explain the Swedish welfare model that prevailed in Swedish society during the post WW II-period. The concept of a people's-home, was first used in 1928 in a speech by Swedish Prime Minister Per Albin Hansson (Meidner 1993, 212).

${ }^{5}$ However, this was not the case. The share became a huge disappointment, and by 2010 the value was reduced to half the launching price in 2000 (Dalarnas Tidningar 2010).
} 
So apart from the obvious role of information and communication technology in facilitating the circulation of capital in the financial markets, the equivalent role of traditional news media should not be overlooked (cf. Hope 2010).

So, let us now look at a more global phenomenon where news media coincide with the interest of, and facilitates the practices of, financial markets. We now move to the accumulation of capital that Marx defines as M-M', money generated out of money (Marx 1867, 1990, 248). The relationship between news media and the financial sector is not new; on the contrary it goes back to the very first European newspaper, owned by a banking family (Almiron, 2010, 68). However, as a consequence of the massive deregulations of the financial sector (banking, credit flows, etc.) and the emergence of new means for financial speculation through information and communication technology in the 1990s, information within news media flows and financial flows started to overlap in real time (Hope 2010, 654). Broadcasters such as Bloomberg and CNBC became engines in the mounting flow of asset transfers within the financial sector, generating a massive speculative financial economy. In the 1980s and 90s large television networks fused with the world of financial transactions, providing vast amounts of financial information to journalists all over the world (Hope 2010). One could argue that finance broadcasting provided the raw material (in the form of digits, index, rates, financial "expert" discourses, etc.) to news outlets all over the world. This raw material was then used in producing news in different media settings in different economic and geographical contexts. A rapid movement on the stock markets somewhere in the global financial system had a direct impact on both actors in the financial sector as well in the media sector. In the mid 1990s these media/finance flows of information were also transferred online, creating an instant flow of financial information on the Internet. The merger of interests between the field of finance capital and news journalism that was visible to a certain extent in the 1980s became more or less standard after the rapid development of information and communication technologies in the 1990s (Hope 2010). In the beginning of the $21^{\text {st }}$ century "most of the top news-media conglomerates have experienced a huge increase in their financial links and dependencies" (Almiron 2010, 152). So considering the instant flow of information through communication systems, the growth within the financial sector exploded in the first years of the past decade. The increase in Web-based financial actors flourished alongside computer generated algorithmic trading, secrete hedge funds, derivative trading, asset-stripping, and so on, creating an enormous build-up of fictitious capital. In all this, the relationship between actors within journalism and in the financial sector became even more blurred, both in case of ownership and personal interests among journalists. For example, highprolific journalists became advisers on financial blogs and the blogosphere "helped to constitute the informational environments of financial print media and business television channels" (Hope 2010, $660)$.

The mutual interest between news and the financial sector was a great factor in the (almost) total failure of journalism in the build up to the economic crisis in 2008 (Almiron, 2010). The general oblivious attitude among journalists and news producers towards the preceding financial break down in 2008 have rendered some internal criticism (see for example Schechter 2009; Fraser 2009), but the overall discussion of the political economy of financial news is still marginal outside critical media research.

So considering the role of financial news outlets and economical journalists, news media have without a doubt contributed to the increasing speculation in the financial system, by aiding the processes of financialization. The 'superfluousness' of financial information, instantly transferred through communication systems, has together with an increasing dependency on, and ownership by, financial actors, contributed to uncritical news flows on economic issues. You could even argue that a major part of the financial news is mere an informational infrastructure of finance capital interests. In relation to what Marx $(1867 / 1990,920)$ identified as the emerging credit system (what is basically today's finance system), the role of banks, credit institutions and other financial actors could not be understated in relation to the compression of time and space through communications systems. Undeniably, the function of ICT's and financial news flows in facilitating the rapid centralization of capital in the hands of financial institutions, establishes them as key actors much as the banks and the credit system in the historic processes of primitive accumulation (Marx 1867, 1990).

\subsubsection{The Global Justice Movement: Violence and Politics}

The global justice movement is at the forefront of the struggle against accumulation by dispossession. It is a diverse but socially and politically coherent movement of movements that addresses the specific relation between capital and processes that resemble the features of primitive accumulation described by Marx. The struggles fought by different social movements are aimed at ongoing processes of peasant expulsions, privatization of natural recourses, the thievery of land and means 
of production, the suppression of indigenous people, the financial system of debts and structural adjustment programs, all coerced by national and global capital aided by brute state power. In conclusion, the global justice movement could be seen as a social and political reaction to the processes that constitute capital accumulation by dispossession (Harvey 2010a, 313).

The mobilizations against a series of global summits towards the end of the last millennium became visible to a transnational public during the WTO-meeting in Seattle in late November 1999. Following an explosion of protests around the world at similar events, the Global Justice Movement made headline news all over the world (Klein 2001). Through the creation of the World Social Forum (WSF) in 2001, the diverse political resistance generated by the dispossession of labour, resources and land, constituted a common ground. The World Social Forum facilitates a unique space for discussions, meetings, seminars, and social contacts that generates diverse political collaborations, platforms, campaigns, and decisions (Sen and Waterman 2009). In short - the WSF and the global justice movement represent the first step in organizing global resistance against capital in an age that has been characterized as post-political (Mouffe 2008).

So, how did the social mobilizations of the global justice movement come to the fore in (Swedish) mainstream news? On the one hand, the more moderate political issues connected to the features of accumulation by dispossession such as debt relief, financial speculation and the consequences of deregulations, did make it into the news flow. The demand for debt relief, taxes on financial speculation and the right to certain basic goods (particularly water), were addressed in the mainstream, and sometimes even endorsed by political commentators and actors outside the global justice movement. On the other hand, at the end, it also became clear that most of the representation focused on the social and political impossibilities of achieving any larger changes within the global economic system. When political action was represented in the news media, such as in the mobilization for a total debt relief, the framing neglected the long-going struggle among social movements against the structural adjustment programs of the IMF and the World Bank. Instead representatives of Western governments were given credit for putting the issue on the agenda of global summits (Ekman 2011). A similar conclusion could be drawn from research made on US news media. As Lance Bennett and colleagues conclude from their study on US news media: "Perhaps the greatest irony in the journalistic construction of the globalization debate is that WEF elites were given disproportionate credit for issues that activists had long before defined and attempted to get into the news on their own terms" (Bennett et al. 2004, 450). The struggles of large social movements against accumulation by dispossession were mostly ignored and when they did come to the fore in the news, their struggles were often depicted as obsolete. In the dominating liberal discourse on globalization, peasant mobilization and struggle were framed as something that stalled wider economic progress and prosperity in the global south. At least this was the case in the mainstream reporting on the political agenda of the World Social Forum (Ekman 2011).

More radical political issues that confronted the very rationale of global economic and political structures were less visible; instead much of the news coverage tended to focus either on what was framed as a political and social incoherence of the global justice movement or at the violence occurring during the protests. In the case of the global protests against summits, the political dimension in the news flow was totally subordinated to reports about violence, or even reports about potential violence. The latter was manifested by news reports on upcoming protests as violent threats, as unavoidable violent confrontations, and even as non-present violence (through comments on the surprisingly peaceful character of demonstrations) (Ekman 2011, 136). When political matters were addressed, the global justice movement was described negatively in relation to the dominant institutional practices and processes in summits (Ekman 2011).

A closer look at the representation of violence reveals that it constitutes one of the primary expectations in the news reporting. The focus on violence forms an element in a far-reaching historical understanding of protests, which is naturalized in the discursive practices between journalism and state/police institutions (cf. Halloran, Elliot and Murdock 1970; Murdock 1981; Carter and Weaver 2003; Doyle 2003; Cottle 2006). Mediated violence tends to reproduce a police-based law and order discourse, and works as a rationalization of power, in which journalism first and foremost reproduces the image of systemic violence as necessary for protecting citizens and for maintaining general order in relation to organized violent protests (cf. Wahl-Jorgensen 2003). So, mediated violence could be viewed as a double-edged sword in relation to the social mobilization of the global justice movement. On the one hand, news media dismiss part of the protests and the protesters for being violent. On the other hand, news media legitimize and justifies systemic violence by mainly disseminating a police discourse of law and order (cf. Galtung 1990). For example, in the news representation of the mobilization against the WTO-meeting in Cancún 2003, news media naturalized the militarization of the meeting by framing it as an issue of "security" (Ekman 2011). Several 
news articles depicted the massive presence of military and police (more than 20.000), military helicopters, military vessels and police barriers as "protection" for the WTO-delegates (Ekman 2011, 157). Simultaneously, the demonstrations were depicted as threats to "free trade" (Ekman $2011,156)$. This form of objective violence emerges at the intersection of state/capital militarization and news media (cf. Zizek 2008).

In conclusion, the news representation of the global justice movement is dominated by hegemonic discourses on globalization, economics, social protests and politics. The rationale of neoliberal ideology is manifested in the dominant discourse of "globalism" (cf. Fairclough 2006). It holds a preferential position in explaining how social change takes place in mediated public political debates during the period of contested neo-liberal hegemony (between 1999-2007, Ekman 2011). News coverage of global mobilization and resistance are ultimately reified as a result of the absence of any larger discussions or explanations of the global economic system that are not intrasystemic. Instead the reality is truncated, simplified and packaged, and complex social relationships are reified in relation to dominant discourses of the global economy (Ekman 2011). As media scholar Berglez $(2006,180)$ argues: journalism "partly embraces and 'shows understanding' for the political struggle against the capitalist system, although in terms of neutralizing the radical dimension of the political struggle (making it less leftist and class-located), thereby paving the way for the transformation of the radical political struggle into another (normal) everyday life practice". So, huge global social mobilizations against accumulation by dispossession, do not gain any significant political legitimization through conventional media exposure.

\subsection{Dispossession of Everyday Online Activity}

The second part, in which Harvey's theory of accumulation by dispossession could be used in relation to media and communication research, is by examining the specific role of online communication systems and platforms. Here Marx's (1867/1990, 668ff) discussion on how surplus value is generated could explain how work performed by users of social media are appropriated by capital and transformed into surplus labour. So here we will tap into the ongoing discussion of how to understand the activity performed by everyday users of social media on Web 2.0 (often refer to as produsers) in relation to capitalist interests (cf. Fuchs 2009; Jakobsson and Stiernstedt 2010). The production of surplus value by exploiting the activity performed on social media sites such as Facebook, YouTube, etc. is made possible by selling users, and more specifically, the output of their work, to advertisers. The concept of media audiences as commodities is well debated within the research field of political economy of communication (cf. Smythe 1982; Mosco 2009, 136ff). The main element in Smythe's (1982) argument is that the audience constitutes the main commodity of the mass media (Mosco 2009, 136). Smythe's concept highlighted the role of media producers in the construction of audiences in relation to advertisers. The idea of audience commodification also located media organizations into the "total capitalist economy" (Mosco 2009, 137), as an integrated part in the circulation of capital. However, the idea of audiences performing work for media owners, for example by watching television, have been largely debated within the field of political economy (Mosco 2009, 137). Media scholar Bolin $(2011,37)$ suggests that viewing television could be understood as "a part of the recreation of the worker's labour power". Watching TV is not an activity that produces something, but instead a process that could be defined as a raw material in the production process undertaken by advertisers and media companies. Thus, watching television is part of the means of production (viewer as statistics), but it can't be considered labour (Bolin, 2011, 37). In the first phase of the circulation of capital, when the capitalist acts as a buyer of commodities, companies purchases statistic on viewer demographics (Mp) used in producing advertisements (cf. Marx 1867/1990). However, Mosco $(2009,137)$ argues that whether Smythe's idea of audiences constituting labour is useful or not could be left aside. Instead the main insight of the materialist approach in Smythe's theory is the concept of a reciprocal relationship in the triad of "media company-audience-advertiser" (Mosco 2009, 137). The idea that mass media are not only ideological producers or transmitters, but also totally integrated in the circulation of capital is unquestionably useful when analyzing the political economy of mass media.

In the case of users of Web 2.0, the process of appropriation is indeed a process of appropriated labour. The work dispossessed by capital is everything users do when they are communicating through various commercial platforms and sites on the Internet. For example, in the case of Facebook and other networking platforms, this process of transferring surplus labour of online activity by everyday users into the circulation of capital, is refined by providing to advertisers specific segments of users, based on the information obtained from Web traffic, preferences and activities on networking sites and other places on the Internet. Here the appropriated labour consists of everything we do when we are online. Most parts of the work performed by users are monitored and 
enclosed by different networking sites, search engines, e-mail services, etc. Here you could actually speak about a process that separates the means of production (intellectual, communicative and creative) from the worker (produsers) (Marx 1867/1990:875). It is not a direct forced separation, but an indirect one. The indirect forcing factors are basically the disadvantages that you might experience when being outside a network platform such as Facebook, for example the loss of jobopportunities, personal connections, social relations, and other immaterial assets. The price of being outside could be measured against the fact that you "sell" all your information and activities to a commercial actor to be able to participate. As a consequence, everyday online activity constitutes a dynamic field of potential surplus labour ready to be transformed into surplus value. This is refined by surveillance systems that track user behaviours and monitor activity by categorizing what is uploaded, "liked" (in the case of Facebook), what your e-mails contains (in the case of Gmail), what Websites you visit on a regular basis, and basically everything that you do when surfing the corporate part of the World Wide Web (Fuchs 2011; Jakobsson and Stiernstedt 2010).

However it is not only the time and the work, in the form of texts, images, videos, and other aspects of personal information (in the form of unpaid labour) that are dispossessed by capital. Network sites such as Facebook also transform the social relations between users and business corporations. When users integrate companies, brands, and other commodities into their everyday social networks, the producer-consumer relationship becomes just another personal relationship, much like the one you have in your everyday social life. For example, Coca Cola has almost 40 million fans on its Facebook page ${ }^{6}$. Since companies, brands and products have their own pages in networking sites such as Facebook, the interaction between business and consumers is, potentially, instant and never ending. The activities on social networks sites also advance commodified individualism by transforming inter-personal communication in relation to products and consumption (cf. Fuchs 2011, 315). The marketing strategies of big multi-national companies aim to captivate the social being in itself, creating milieus that colonize every lasting part of private and personal life. This reflects, or indeed advances, what Jhally $(2000,29)$ refers to as the "overwhelming...commercial colonization of our culture". The most ultimate appearance of this reification process is probably the ideology and practice that indulges the construction of the individual self as a brand, or as a platform for commercial branding. This is a phenomenon that is highly visible in the blogosphere. In the anticipation of catching the eye of advertising firms, in order to get some revenue from the business sector, thousands of bloggers act like advertising posters for brand names and products by incorporating and mediating their consumption in communication platforms in Web 2.0. Consequently communication platforms and infrastructures constitute a highly dynamic arena for dispossession of labour and the "life" outside ordinary wage-labour. When free time and the social conditions of every-day life become integrated in the production-consumption relation of capital accumulation, users are reified simply by being unpaid producers of images, texts, videos, stories, etc., that transform them into commodities that are sold to advertisers and companies. All the user-generated content on commercial platforms such as Facebook are owned, stored and processed with the purpose of generating surplus value, this is of course the whole idea of corporate investments. In fact, the Internet is overflowed by capital interests, so you could primarily characterize it as a "space... dominated by corporations (Fuchs 2011, 337).

The rapid development of information and communication technology also has implications for the commodification of public space. For example, in relation to the research on the privatization of public space (cf. Harvey 1989; Sennett 1992), contemporary mobile phone technology has new and dynamic ways of luring subjects into the production-consumption relation of capital accumulation. The traditional debate on the privatization processes of public space has focused on how public spaces are transformed into shopping malls, corporatized areas, gated communities and so on, creating what Sennett (1992) refers to as "dead public spaces". These sanitized and corporately controlled commodified spaces are increasingly visible all over the globe. The most striking feature of these spaces is how they affect social relations and behaviours, by incorporating and naturalizing patterns of consumption into the organization of everyday life.

However, with the rapid development of mobile phone technology, all public spaces become potentially commodified. The mere fact that a person may well be constantly logged in to her/his Facebook account through the mobile phone opens up for a whole new dimension of the commodification of public space. This suggests that you are, at least potentially, submitted to constant corporate surveillance, monitored by several actors integrated in your online networks, and thus performing unpaid labour that is appropriated by capital. This has serious implications for the very idea of privacy (cf. Fuchs 2011, 313) and in fact the whole notion of what constitutes free time, what constitutes work and public space. Since smart phones enable the interaction between conventional

\footnotetext{
${ }^{6}$ In the form of "likes" (Facebook 2012).
} 
advertisement (billboards, posters, etc.) and online activities by the use of Quick response-codes (QR) etc., the activities in physical public space (whether in the subway on your way to work or at the billboard posted on the wall in your neighbourhood) are integrated with your activities in your virtual space. The "apps" that seems to facilitate individual communication patterns, also colonize private subjects and alter patterns of social behaviour in everyday life by transferring them into the production-consumption relation of capital accumulation. The "apps" have a double-commodified character, they are goods that users are purchasing, and they also engage users in more consumer-based activities. Needless to say, the development of mobile phones and the massive dislocation of space when performing online communication also open up for a more positive and creative non-commercial communicative behaviour. It can enable political and social mobilization and resistance to capital and the political structures that uphold the exploitation of labour (Fuchs 2011). The problem is of course not rapid development of communication technology, but the colonization of communicative social relations by capital.

In relation to the features of accumulation by dispossession, the surveillance and invasion of privacy by corporate Internet owners such as Facebook, MySpace, Gmail, YouTube, and so on, could be understood as means to expand the reification of social relations and the self. But I will also like to stress the possibilities of one other factor immanent in the processes of primitive accumulation - violence. If we accept Žižek's (2008) idea of systemic violence as inherited by a subjective (physical) and an objective (structural or symbolic) dimension, we could argue that corporate surveillance of private subjects through technologies that monitor the information we upload, and the activities we participate in our online activities, constitute a potential objective violence. The ownership of such a great amount of information on the private being of individuals and groups, without any transparency of how this huge bundle of information is stored or used, could be comprehended as a potential threat to subjects. Besides the fact that advertised based networks and platforms already censor and forbid certain content and activities in order to satisfy advertisers (Fuchs 2011), the information of private subjects could potentially be sold to anyone. This implies that information regarding political issues or other socially sensitive oriented matters (how private the user may think they are in respect to privacy settings and person-to-person communication) could be gathered and used for purposes other than commercial advertising. So, in this respect, the surveillance of the corporate Internet could be comprehended as a potential threat simply because there is no guarantee what the information will be used for, who is buying it and to what extent private/personal information is circulated. Sensitive information, owned, gathered and processed by companies like Facebook, could be sold as commodities to actors within the militaryindustrial complex, or to political actors. Since surveilled subjects, and the constant flow of information emanating from users, are commodities in the market place, objective violence appears as an underlying threat to those whose personal/private information contests the current interests of the ruling political and economical powers.

\section{Conclusion}

In order to identify the role and function of news media and communication systems in the ongoing accumulation of capital, I have argued that Marx's (1867/1990) concept of primitive accumulation and Harvey's $(2003 ; 2006 ; 2010)$ theory of accumulation by dispossession could contribute to critical media and communication research. The concept of primitive accumulation as a continuing set of characteristics within the expanded reproduction of capital is useful in order to understand some distinctive elements in contemporary news media content, news flows and news media systems, and within the development of online communication platforms. The processes that distinguish capital accumulation in the time of neo-liberal global expansion, coincide with many of Marx's descriptions of how pre-capitalist modes of production were transformed into capitalism. The ongoing global crisis reveals that expanded reproduction of capital is facing many constrains, and thus the search for new ways to secure the accumulation of capital indicate that more and more aspects of our societies are, and will continue to be, relocated into capital property relations. In these transformation processes, new areas of commodification are located and new ways of appropriating unpaid (free time) labour are developed. In these processes news media systems and online communication play a considerable dynamic part. This article has targeted two areas in which primitive accumulation/accumulation by dispossession could contribute to the research field of the political economy of media and communication.

First, I have addressed the specific ideological dimension of news and the function of financial news flows and systems in relation to capital accumulation. Second, I have discussed various aspects of how surplus value is produced in relation to everyday Internet use and in relation to the rapid advancement of communication technology. 
The first aspect that can be summarized here is how news media facilitate the privatization of the commons, endorse the transfer of public assets into private property relations and depoliticize and delegitimize social mobilization against capital. Furthermore the article shows how news flows and news media systems coincide and interlink with financial flows and actors, thus constituting a close relationship between financial news and the finance sector. This relationship is also attached to the rapid changes within information and communication technology and the compression of time and space in capital accumulation.

The second aspect dissects the political economy of Web. 2.0 with a specific focus on how produsers are commodified and sold to advertisers and how the work performed by users in network platforms such as Facebook is appropriated by capital. The commodification of social media and Internet use has potentially far-reaching possibilities. The colonization of free time, the total commercialization of recreation, personal social relations and even the self, by capital, is made possible by the corporate control over the user dimension in social networks and other social media platforms. Internet surveillance, in which commercial gathering, owning and processing of private information, is one of the major assets in the circulation of capital and could be viewed as a potentially threat to users, and even a part of the objective violence constituted in capitalist exploitation.

Undeniably this article has focused on the negative aspects of how mainstream news media facilitates and reproduces the exploitation of capital, how the use of new information/communication technology become colonized by capital, and how commodification processes tend to dominate the flow of information in global media and communication systems. However, there are also several aspects of media production and communication technology that point in an opposite direction and open up for counter-hegemonic formations in a global context. The dynamic production and circulation of alternative and radical media and the ongoing struggle for a commons-based Internet are important aspects to highlight within critical media and communication research. The realm of news media production and communication technologies is never monolithic, thus it also needs to be theorized and analyzed from the perspective of emerging alternatives (cf. Fuchs 2011). After all, the seminal theory of Marx on capitalism also points out alternatives to the total exploitation of capital.

\section{References}

Almiron, Núria. 2010 Journalism in Crisis. Corporate Media and Financialization. New Jersey: Hampton Press. Arrighi, Giovanni. 2010. The Long Twentieth Century. London: Verso.

Bennett, W. L. Pickard, V. lozzi, D. Schroeder, C. Lagos, T. and Caswell, E. 2004. Managing the public sphere: Journalistic construction of the great globalization debate. Journal of Communication 54: 437-455.

Berglez, Peter. 2006. The Materiality of Media Discourse - On Capitalism and Journalistic Modes of Writing. Örebro: Örebro Studies in Media and Communication 4.

Bolander, Hans. 2000a. Åtta skäl som talar för Telia. Expressens Hans Bolander: Därför kan aktien bli en vinnare. Expressen, May 21. 6.

Bolander, Hans. 2000b. Börsexperterna tror på klipp. Expressen, May 31. 6.

Bolin, Göran. 2011. Value and the Media. Farnham and Burlington: Ashgate.

Callinicos, Alex. 2009. Imperialism and Global Political Economy. London: Polity Press.

Carter, Cynthia. and Weaver, C. K. 2003. Violence and the Media. Buckingham and Philadelphia: Open University Press.

Cottle, Simon. 2006. Mediatized conflict: developments in media and conflict studies. New York: Open University Press.

Dalarnas Tidningar. 2010. Så mycket har Teliaaktien fallit. Dalarnas Tidningar 14 June 2010. Accessed 25 February 2012. http://www.dt.se/nyheter/dalarna/1.3086140-sa-mycket-har-teliaaktien-fallit

Doyle, Aaron. 2003. Arresting Images: Crime and Policing in Front of the Television Camera. Toronto: Toronto University Press.

Ekman, Mattias. 2011. The Global Justice Movement in Swedish Media: Hegemonic formations in the relation between journalism and capitalism. (English title) Stockholm: JMK.

Facebook. 2012. Facebook CocaCola. Accessed 20 February 2012. http://www.facebook.com/cocacola

Fairclough, Norman. 2006. Language and Globalization. New York: Routledge.

Fraser, Matthew. 2009. Five reasons for crash blindness. British Journalism Review 20(4): 78-83.

Fuchs, Christian. 2009. Some reflections on Manuel Castells' book Communication Power. tripleC - Cognition, Communication, Co-operation: Open Access Journal for a Global Sustainable Information Society 7(1): 94-108. Accessed 27 February 2012. http://www.triple-c.at/index.php/tripleC/article/view/136/90

Fuchs, Christian. 2011. Foundations of Critical Media and Information Studies. New York: Routledge.

Galtung, Johan. 1990. Cultural Violence. Journal of Peace Research. 27(3): 291-305.

Gramsci, Antonio. 1929-35, 1971. Selections from the Prison Notebooks. New York: International Publishers.

Halloran, James. D. Elliot, Philip. and Murdock, Graham.1970. Demonstrations and Communication: A Case Study. Harmondsworth, England: Penguin Books.

Hartsock, Nancy. 2006 Globalization and Primitive Accumulation: The Contributions of David Harvey's Dialectical Marxism. In David Harvey. A Critical Reader. Edited by Castree, N. and Gregory, D. Malden, MA: Blackwell.

Harvey, David. 1982. 2006. The Limits to Capital. London: Verso.

Harvey, David. 1989. From Managerialism to Entrepreneurialism: The Tansformation of Urban Governance in Late Capitalism. Geografiska Annaler. 71B: 3-17. 
Harvey, David. 2003. The New Imperialism. Oxford: Oxford University Press.

Harvey, David. 2005. A Brief History of Neoliberalism. Oxford: Oxford University Press.

Harvey, David. 2006. Spaces of Global Capitalism: A Theory of Uneven Geographical Development. London: Verso.

Harvey, David. 2010a. A Companion to Marx's Capital. London: Verso.

Harvey, David. 2010b. The Enigma of Capital: And the crises of Capitalism. London: Profile Books.

Hesmondhalgh, David. 2007. The Cultural Industries. London: Sage.

Hope, Wayne. 2010. Time Communication, and Financial Collapse. International Journal of Communication 4 2010: 649669.

Jakobsson, Peter. and Stiernstedt, Fredrik. 2010. Pirates of Silicon Valley: State of exception and dispossession in Web 2.0. First Monday Volume 15, Number 7. Accessed February 25, http://firstmonday.org/htbin/cgiwrap/bin/ojs/index.php/fm/article/view/2799/2577

Jhally, Sut. 2000. Advertising at the edge of the apocalypse. In Critical studies in media commercialism. Edited by R. Andersen and L. Strate. New York: Oxford University Press.

Klein, Naomi. 2001. Reclaiming The Commons. New Left Review nr.9

Luxemburg, Rosa. 1913, 2003. The Accumulation of Capital. London: Routledge Classics.

Magnusson, Karl. Erik. 2000. Telia spås en bra start. Experterna råder till köp av den nya folkaktien. Göteborgs-Posten, May 22. 35 .

Marx, Karl. 1857,1993. Grundrisse: Foundations of the critique of political economy. London: Penguin Classics.

Marx, Karl. 1867,1990. Capital: Volume 1: A Critique of Political Economy. London: Penguin Classics.

Marx, Karl. 1885,1992. Capital: Volume 2: A Critique of Political Economy. London: Penguin Classics.

McChesney, Robert. W. 2007. Communication Revolution. London: The New Press.

Mediearkivet. 2012. Accessed on February 25. https://web.retriever-info.com/

Meidner, Rudolf. 1993. Why did the Swedish Model Fail? Socialist Register Vol. 29: 211-228.

Mosco, Vincent. 2009. The Political Economy of Communication. Second Edition. London: Sage Publications.

Mouffe, Chantal. 2008. Om det politiska. Hägersten: Tankekraft.

Murdock, Graham. 1981. Political Deviance: the press presentation of a militant mass demonstration. In The Manufacture of News: social problems, deviance and the mass media. Edited by Cohen, S. and Young, J. London: Constable.

Mårtenson, Bo. 2003. Den televiserade ekonomin- Nyheter om statsbudgeten 1980-1995. Stockholm: JMK.

Norlin, Arne. 2000. Så köper du Telia - Den nya folkaktien. Aftonbladet, April 15. 5.

Olivera, Oscar, and Lewis, Tom. 2004. Cochabamba! Water Rebellion in Bolivia. Boston: South End Press.

Schechter, Danny. 2009. Credit crisis: How did we miss it? British Journalism Review 20(1): 19-26.

Sen, Jai, and Waterman, Peter. (eds.) 2009 World Social Forum Challenging Empires. Montreal/New York/London: Black Rose Books

Sennett, Richard. 1992. The Fall of Public Man. New York: W.W. Norton.

Smythe, Dallas. W. 1982. On the Audience Commodity and its Work. In Media and Cultural Studies Keyworks. Edited by Durham, M. G and Kellner, D. M. 2006. Malden, MA: Blackwell.

Viscovi, Dino. 2006. Marknaden som monster och monster. Ekonomiska experter och nyheter om ekonomi i Rapport 19781998. Göteborg: JMG.

Wallerstein, Immanuel. 2001. Liberalismens död. Stockholm: Vertigo.

Wahl-Jorgensen, Karin. 2003 Speaking Out Against the Incitement to Silence: The Brittish Press and the 2001 May Day Protests. In Representing Resistance- Media, Civil Disobedience and The Global Justice Movment. Edited by Opel, A. and Pompper, D. Westport/CT: Praeger Publishers.

Wendel, Per. 2000. Så köper du folkaktien. Expressen. May 21. 6.

Žižek, Slavoj. 2008 Violence. Six sideways reflections. New York: Picador.

Žižek, Slavoj. 2009 First as Tragedy, Then As Farce. London: Verso.

\section{About the Author}

Mattias Ekman

Mathias Ekman is working as a lecturer in the department of Media Studies at Stockholm University. He has contributed to a chapter in the Sage Encyclopedia of Social Movement Media (2011). 